\title{
Systemic Efficiency Assessment of Municipal Solid Waste Management in the Suburban Municipality
}

\author{
Grzegorz Przydatek and Emilia Basta \\ Engineering Institute, State University of Applied Sciences in Nowy Sącz Zamenhofa 1a street, 33- 300 \\ Nowy Sącz. Poland
}

\begin{abstract}
A comparative analysis of municipal waste generated in a selected suburban municipality in the mountain area of the European Union showed a collection of mixed and segregated waste, taking into account 10 fractions out of which 6 fractions were collected irregularly. The mass of waste generated was dominated by mixed waste with the highest amount of $50.50 \mathrm{Mg}$ and an average value of $32.96 \mathrm{Mg}$. The highest result of the amount of collected waste in the municipality of $158.32 \mathrm{Mg}$ fell at bulky waste, which was collected irregularly. Within 48 months a favorable increase in the mass of collected segregated waste was noted, and thus their recovery with the highest average close to $30 \mathrm{Mg}$. Despite the increase of segregated waste accumulation rate per capita it was lower of $0.56 \mathrm{~kg}$ than mixed waste accumulation rate per month, which confirms the need to deepen ecological awareness. Keywords: municipal waste, waste management, collection, rate accumulation
\end{abstract}

\section{Introduction}

Waste is a growing problem in both highly developed and still developing countries as well as in underdeveloped countries [1]. Particular attention is paid to municipal waste, which may be generated in households and industry [2].

In general, an increase in consumption leads to an increase in the amount of waste, which may additionally affect the deterioration of the natural environment [3]. As the amount of waste generated increases, the efficiency of its recovery should be improved. Resource recovery is one of the main objectives of a sustainable waste management system [4]. Den Boern et al. [5] demonstrated that the effectiveness of waste management depends on the morphological composition of waste, and in particular on selective waste collection and seasonal management of organic waste.

Regulations in waste management in the European Union countries define the framework of waste management to minimize their impact on the environment. Since mid-2013, local authorities in Poland, in accordance with the assumptions of Directive 1999/31/WE [6] and Directive 2008/98/WE [7], have been obliged to prevent their occurrence to the best of their abilities [8]. The next place in the waste management hierarchy is occupied by reuse and recycling. An important aspect of waste management is its monitoring to reduce excessive waste generation [9]. 
The aim of the paper was to assess the effectiveness of waste management in a suburban municipality located in southern Poland in a mountainous area, taking into account national systemic changes in waste management.

\section{Research Materials and Method}

The monthly amounts of waste generated in individual months from 2014 to 2017 were used to carry out the assessment. The qualitative and quantitative data on waste were obtained on the basis of a questionnaire inquiry addressed to a selected municipality. Mixed municipal waste and waste plastic, glass, paper and cardboard, which were collected cyclically and analysed.

In addition, data on organic waste, demolition waste, bulky waste, batteries and used tires were used [10]. These, in turn, were collected sporadically. The paper determines the indices of mass accumulation of waste per capita per month in division into mixed and segregated waste. The number of inhabitants of the municipality was determined on the basis of Statistics Poland (SP) [11]. The results of accumulated waste in the selected municipality were analysed statistically using the Statistica 13 (StatSoft) program, including descriptive statistics including: minimum, maximum, arithmetic mean and standard deviation (SD). The number of data in the analysed period amounted to 48 samples each for the value of waste collected non-selectively and selectively, including glass, plastic and paper waste. Time series were used to determine the course of variable trends and the Pearson coefficient of linear correlation was applied due to the normal distribution of the studied variables.

The study covered the Kamionka Wielka municipality located in the Małopolska Voivodeship (southern Poland; 49.58'20"N, 20.83'74"E) in a mountainous region, on the border of the Beskid Sądecki and the western part of the Beskid Niski due to its location in the vicinity of the city of Nowy Sącz, one of the third largest in the Małopolska Region. This settlement unit is administratively divided into 8 village authorities. In the economic sphere, the vast majority of them are entities connected with services.

\section{Waste management}

Until the first half of 2013, the inhabitants of the municipality remained the owners of municipal waste. At that time, the waste collection was carried out by export companies on the basis of individual agreements with property owners. Starting from the second half of 2013, all inhabited and uninhabited properties are covered by the waste collection, and the Municipality has become a waste owner and supervises waste management from collection to disposal to recovery and disposal sites, in accordance with the provisions of the Act of 13 September 1996 [12]. Waste generated in the municipality is usually collected in plastic bags with a capacity of $120 \mathrm{dm}^{3}$. Containers are used less frequently and usually with capacities of $120 \mathrm{dm}^{3}, 1.1 \mathrm{~m}^{3}$ and $5 \mathrm{~m}^{3}$. Larger containers are used to collect waste in public facilities. In the years 2014-2017, waste collection usually took place at a frequency of two to four times per month. The municipal waste was delivered to the Regional Municipal Solid Waste Processing Plants in accordance with the proximity principle, where it was recovered and disposed of. 


\section{Results}

\subsection{Population}

In the years 2014-2017, the number of inhabitants of the municipality at the end of June in individual years ranged from 10,071 to 10,274, which showed an increase of 203 people. Whereas, the number of inhabitants as of 31 December in the analysed years ranged from 10,100 to 10,329 and finally confirmed the increase by 229 people [11].

\subsection{Municipal waste}

Tables 1 and 2 and Figures 1 and 2 show the amount of mixed and segregated waste, including waste paper and board, glass and plastic, which were collected regularly in each month of 2014-2017.

The amount of mixed waste collected in the municipality with a population of approximately 10,000 inhabitants ranged from 21.10 to $50.50 \mathrm{Mg}$ with an average of $32.96 \mathrm{Mg}$, which was the highest in the whole research period (Tab. 1). The lowest result of the amount of non-selectively collected waste was recorded in 2016 (February) and the highest in 2017 (December) (Fig. 1). For this waste, the highest standard deviation of $7.40 \mathrm{Mg}$ was found (Tab.1). Within 48 months, a downward trend in the amount of generated mixed waste was observed (Fig. 3). For the amounts of separately and regularly collected waste, the extreme values ranged from 16.90 Mg in 2014 (January) to $44.70 \mathrm{Mg}$ in 2017 (September) (Fig. 1). Both the mean value and the standard deviation were lower than the previous one by $3.08 \mathrm{Mg}$ and $1.26 \mathrm{Mg}$, respectively (Tab.1). In the analysed period, a favorable trend of increased weight of recovered segregated waste by $16.35 \mathrm{Mg}$ was observed (Fig. 3). Their share in the weight of collected waste ranged from $31.6 \%$ to $57.3 \%$. The highest share was recorded in 2015 . The total amount of collected municipal waste within 4 years ranged from 713.97 to $876.64 \mathrm{Mg}$. The largest mass of waste was recorded in 2016.

Table 1. Description statistics on basis data of waste and frequently collection from 2014 to 2017

\begin{tabular}{|l|l|l|l|l|l|}
\hline \multirow{2}{*}{ Type of waste } & Min. & Max. & Average & SD & $\begin{array}{l}\text { Collection } \\
\text { frequency }\end{array}$ \\
\cline { 2 - 6 } & $(\mathrm{Mg})$ & $(\mathrm{Mg})$ & $(\mathrm{Mg})$ & $(\mathrm{Mg})$ & {$[$ month] } \\
\hline Mixed & 21.10 & 50.50 & 32,96 & 7.40 & 48 \\
\hline Segregated & 16.90 & 44.70 & 29.88 & 6.14 & 48 \\
\hline Paper and capboard & 0.00 & 5.20 & 2.68 & 1.31 & 48 \\
\hline Glass & 6.67 & 21.90 & 13.15 & 3.36 & 48 \\
\hline Plastic & 6.89 & 22.76 & 14.05 & 3.63 & 48 \\
\hline
\end{tabular}

The index of weight accumulation of mixed waste in the analogous period was from $2.66 \mathrm{~kg}$ (January) to $4.89 \mathrm{~kg}$ per capita (October) in 2017 with an average value of $3.95 \mathrm{~kg}$ per capita (Fig. 1). The values for the accumulation of segregated waste per capita, which ranged from 1.69 to $4.33 \mathrm{~kg}$, were slightly lower. The highest index was recorded in 2017 (September) with an average of $3.39 \mathrm{~kg}$ and the lowest in 2014 (January) (Fig. 1).

Table 2. Basic data of other waste and frequently collection from 2014 to 2017

\begin{tabular}{|l|c|c|c|}
\hline $\begin{array}{c}\text { Type of } \\
\text { waste }\end{array}$ & Min & Max & $\begin{array}{c}\text { Collection } \\
\text { frequency }\end{array}$ \\
\cline { 2 - 4 } & $(\mathrm{Mg})$ & $(\mathrm{Mg})$ & [month] \\
\hline Organic & 0.00 & 9.10 & 7 \\
\hline
\end{tabular}




\begin{tabular}{|l|l|l|l|}
\hline Demolition & 0.00 & 10.50 & 4 \\
\hline Bulky & 0.00 & 158.32 & 8 \\
\hline Drugs & 0.00 & 0.05 & 13 \\
\hline Batteries & 0.00 & 0.02 & 1 \\
\hline Tires & 0.00 & 5.80 & 1 \\
\hline
\end{tabular}

Table 3. Statistically significant Pearson rank correlation values between type of regulary segregated waste

\begin{tabular}{|l|l|l|l|l|}
\hline Variable & $\begin{array}{l}\text { Segregated } \\
\text { waste }\end{array}$ & $\begin{array}{l}\text { Paper and capboard } \\
\text { waste }\end{array}$ & $\begin{array}{l}\text { Glass } \\
\text { waste }\end{array}$ & $\begin{array}{l}\text { Plastic } \\
\text { waste }\end{array}$ \\
\hline Segregated waste & & 0.07 & $\mathbf{0 . 8 5}$ & $\mathbf{0 . 8 8}$ \\
\hline Paper and capboard waste & 0.07 & & -0.13 & -0.11 \\
\hline Glass waste & $\mathbf{0 . 8 5}$ & -0.13 & & $\mathbf{0 . 5 6}$ \\
\hline Plastic waste & $\mathbf{0 . 8 8}$ & -0.11 & $\mathbf{0 . 5 6}$ & \\
\hline
\end{tabular}

Bolding the value of statistics means, that the relationship is statistically significant at $p<0.05$

The amount of collected waste paper and cardboard was from $0.45 \mathrm{Mg}$ in 2014 (May) to $5.24 \mathrm{Mg}$ in 2015 (February) with an average of $2.68 \mathrm{Mg}$. In turn, the amount of collected glass waste was higher and ranged from $6.67 \mathrm{Mg}$ to $21.90 \mathrm{Mg}$ with an average of $13.15 \mathrm{Mg}$. The highest result was recorded in 2016 (April) and the lowest in 2014 (January). Extreme results of collected plastic waste ranged from 6.89 Mg (January 2014) to 22.76 Mg (August 2017) with an average of $14.05 \mathrm{Mg}$ (Tab. 1).

Table 2 presents the amount of organic, bulky and demolition waste, medicines, batteries and tires collected selectively in the suburban municipality between 2014-2017. The largest amount of $158.32 \mathrm{Mg}$ of collected waste was in large-size waste in 2017. The collection of this waste took place within 8 months. Sequentially, the amount of selectively collected demolition and organic waste was more than 15 times lower. The number of collected tires did not exceed $6 \mathrm{Mg}$, with collection recorded only in one month. The smallest amount of separately collected 0.02 and $0.05 \mathrm{Mg}$ waste concerned respectively to the used batteries and expired medicines. The latter were collected most frequently within 13 months.

\subsection{Comparative analysis}

Average values of collected mixed waste in the municipality ranged from $28.65 \mathrm{Mg}$ to 40.69 $\mathrm{Mg}$ in 2015 and 2017, respectively. The average results for the accumulation of segregated waste were lower, ranging from 25.96 (2014) to $34.92 \mathrm{Mg}$ (2017). Among three fractions of segregated waste in the last year under consideration, the highest averages exceeding $16 \mathrm{Mg}$ were characteristic for plastic and glass waste, which was over two times lower than the highest averages for mixed waste. The lowest average quantity of collected waste was $1.80 \mathrm{Mg}$. These extreme average values of separately collected waste occurred simultaneously in 2017 (Fig. 2). 

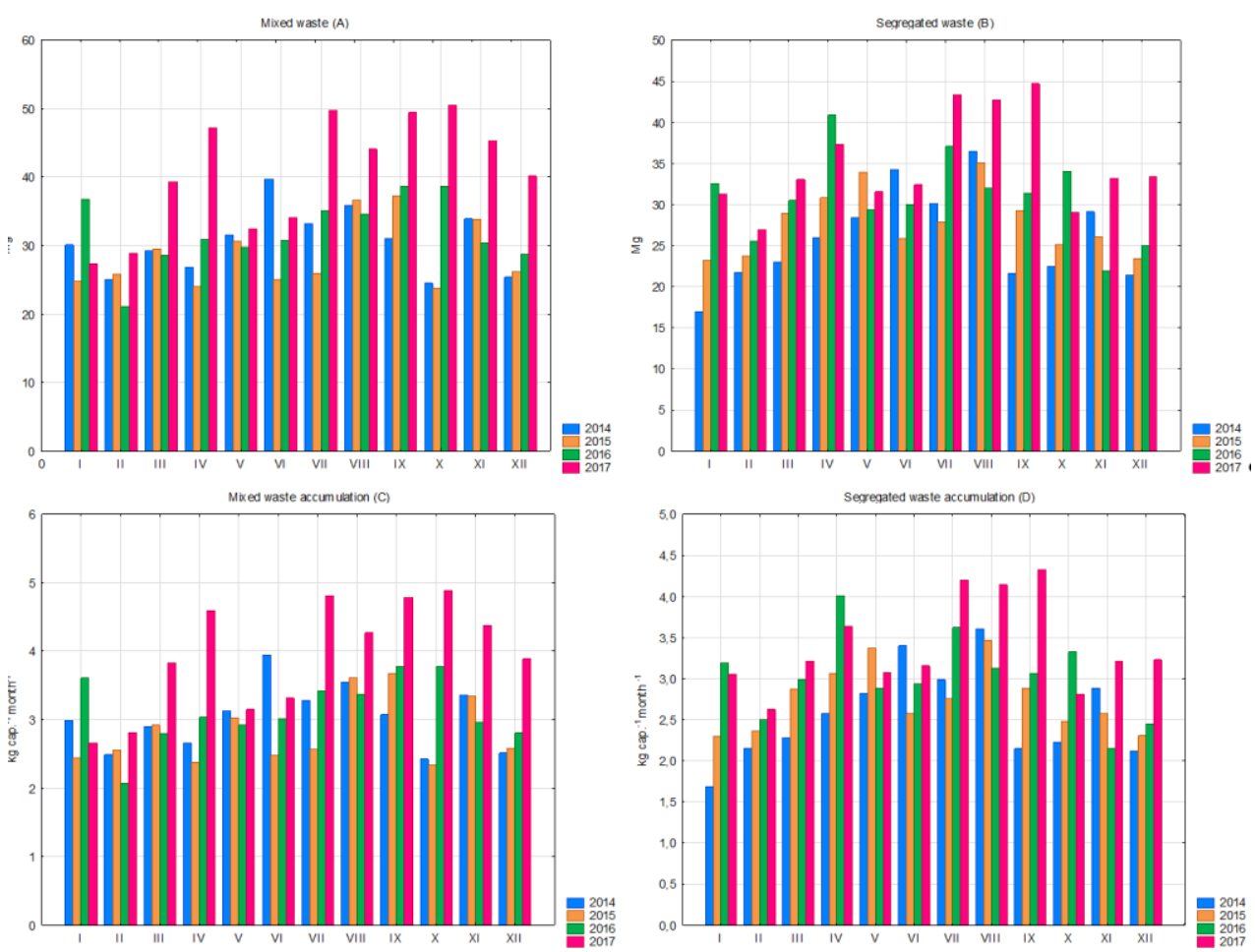

Fig. 1. Produced waste in the suburban community divided into; mixed waste (A), segregated waste (B), mixed waste accumulation per capita per month (C), segregated waste accumulation per capita per month (D) in years 2014-2017

Correlation relations occurred between the segregated municipal wastes. A statistically significant positive correlation occurred between segregated waste and plastic waste $(\mathrm{r}=0.88$, $p<0.05)$ and glass waste $(\mathrm{r}=0.85, p<0.05)$ (Fig. 4). A significant correlation was also found between glass and plastic waste $(\mathrm{r}=0.56, p<0.05)$. Statistically, insignificant correlation results were observed between segregated waste, paper and cardboard waste. Similarly, insignificant but negative correlations were observed between paper and cardboard waste, glass and plastic waste (Tab. 3).

\section{Discussion}

In the suburban municipality with over 10,000 inhabitants, an increase of 229 persons within four years was noticeable. In this area, 10 fractions of waste were collected. However, each month four fractions of waste were collected on a regular basis, which included mixed and segregated waste such as paper and cardboard, glass and plastic. Apart from the regular collection of waste, tires, medicines, demolition and bulky waste were collected irregularly. The largest amount of $158.32 \mathrm{Mg}$ was collected from the last mentioned waste. The amount of separately collected waste reached its lowest result in January $(16.90 \mathrm{Mg})$, while the highest in September $(44.70 \mathrm{Mg})$, which showed a seasonal variability. The trend of increasing the weight of segregated waste by over $10 \mathrm{Mg}$ and their share in the total weight of waste, which exceeded $30 \%$ and showed positive changes in waste management, should be considered as positive. The upward trends in the accumulation of segregated waste were also shown by Johari et al. [13]. 

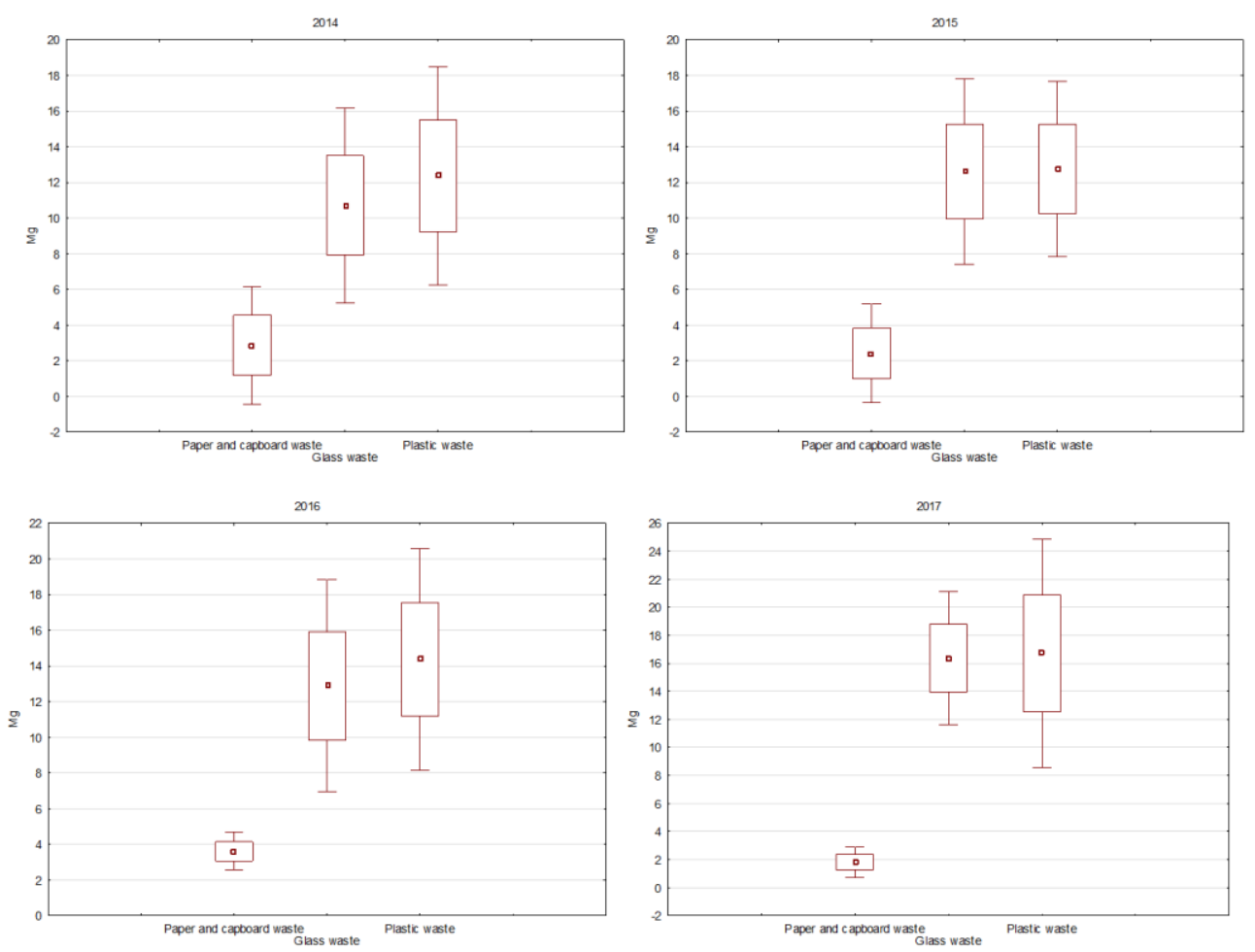

Fig. 2. Average amount of selectively collected waste in the division into 3 fractions in years 2014-2017
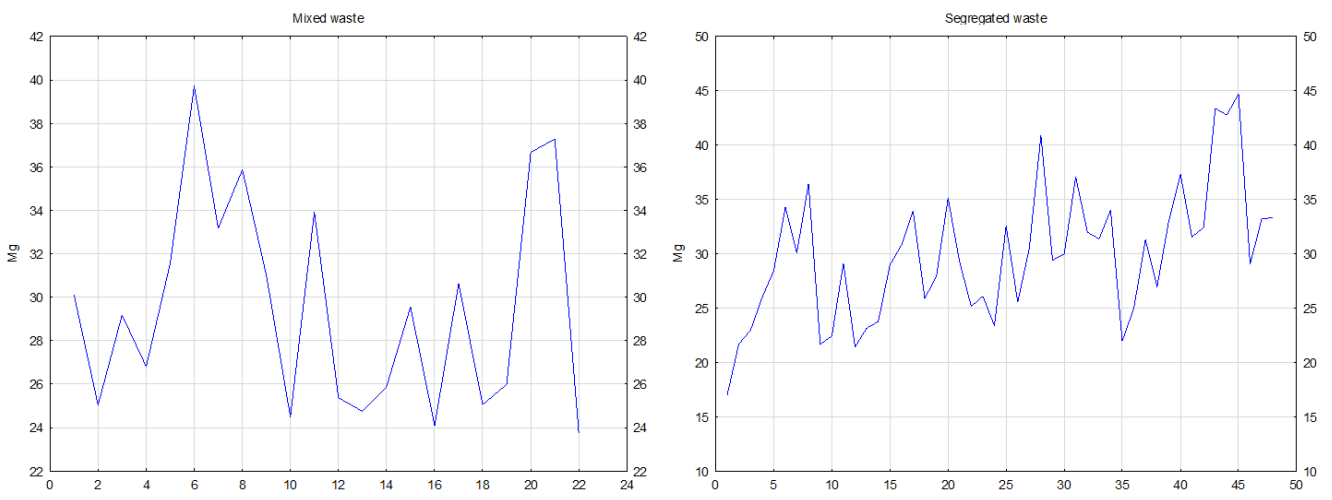

Fig. 3. Trends of changes quantity selectively and non-selectively collected waste in 48 months

A similar share in the mass of separately collected waste in the municipalities in Małopolska before waste management system changes has been shown by Przydatek [14]. In general, the amount of collected municipal waste within four years reached the highest value of $878.64 \mathrm{Mg}$ in 2016 as compared to the dominant amount of mixed waste with an average of $32.96 \mathrm{Mg}$. For this fraction of waste, there was also a characteristic downward trend, which also has been shown by Przydatek et al. [15] in a rural municipality after waste management system changes. 

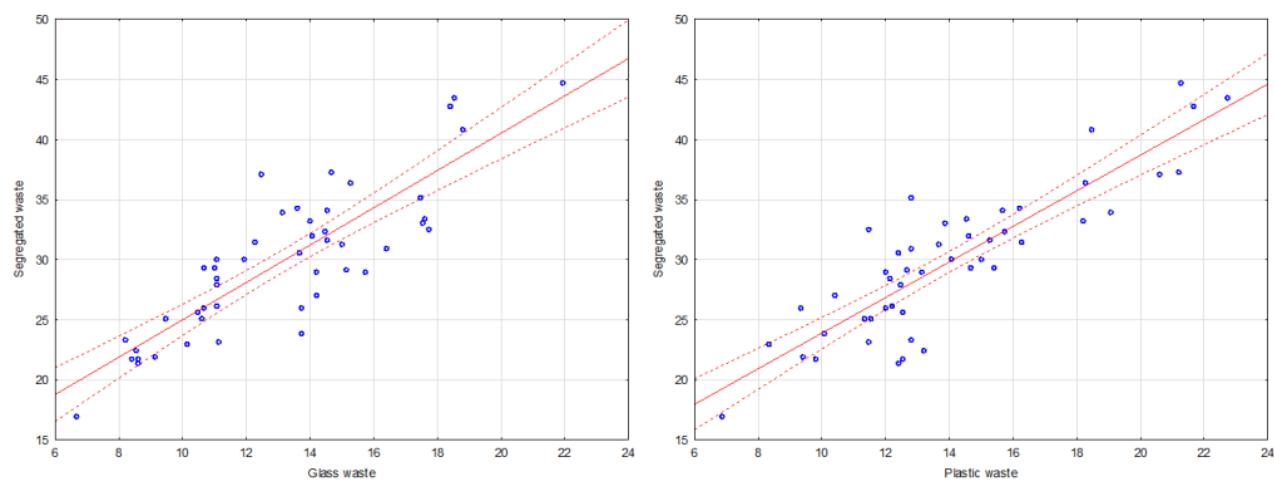

Fig. 4. Statistically significant Pearson rank correlation between fraction of selectively collected waste ( $p$ $<0.05)$

An important index is the mass accumulation of waste per capita. In the case of segregated waste, the highest accumulation of waste per average inhabitant per month amounted to $4.89 \mathrm{~kg}$ and was slightly lower by $0.56 \mathrm{~kg}$ in relation to the accumulation of mixed waste, which also showed the occurrence of favorable changes in waste management after 2012.

The average results of collected waste prove that in the suburban area of the municipality a systematic increase in the amount of waste by $1.50 \mathrm{Mg}$ on average was observed. In the opinion of Macias et al. [16], a greater increase in the mass of segregated municipal waste can be observed in urban areas. Tirado-Soto and Zamberlan [17] have even shown an increase of about $40 \%$. The difference between the averages of results of non-selectively and selectively collected waste did not exceed $6 \mathrm{Mg}$ and the highest average results occurred after waste management changes in 2017.

Correlation relations were noticeable between the segregated municipal waste. The strongest correlation was observed between segregated waste and plastic waste, which suggests its impact on the growth of recycling. A positive correlation was also found between glass and plastic waste, suggesting a positive effect of its content on the balance of recycled waste after changes in waste management. Such a correlation relationship was also demonstrated by Przydatek et al. [18].

\section{Conclusions}

On the basis of the assessment of system waste management in the selected suburban municipality in 2014-2017, the following conclusions can be drawn:

Mixed and segregated waste, including three fractions with the highest amount of $50.50 \mathrm{Mg}$ and the average of $32.96 \mathrm{Mg}$ occurring to non-segregated waste, were collected regularly each month.

Six types of waste were collected irregularly, with the highest mass of $158.32 \mathrm{Mg}$ for bulky waste, which has been collected 8 times.

Within 48 months, the amount of segregated waste has been showing an upward trend with an increase in the number of inhabitants, while a downward trend was observed in the case of mixed waste.

The rate of mass accumulation of mixed waste per capita (2.66-4.89 $\mathrm{kg}$ per month) was slightly lower by $0.56 \mathrm{~kg}$ in relation to segregated waste, which confirms the dominance of mixed waste despite system changes in waste management after 2012.

Among the average values of collected segregated waste in the municipality, a systematic increase of $1.50 \mathrm{Mg}$ on average was observed, which indicated the progressing changes, resulting in increased waste recycling. 
There was a strong correlation between segregated waste and plastic waste, suggesting an impact on waste recycling increase

Acknowledgements The authors of the paper would like to thank of State University for financial support which enabled the study to be conducted.

\section{References}

1. M.A. Hannan, A.I. Abdulla, M. Mamun, A. Hussain, H. Basri, R.A. Begum, A review on technologies and their usage in solid waste monitoring and management systems: issues and challenges. Waste Manag. 43, 509-523 (2015)

2. OECD, Sector case studies: household energy and water consumption and waste generation: trends, environmental impacts and policy responses. (ENV/EPOC/WPNEP(2001)15/FINAL). Organisation for Economic Cooperation and Development Environment Directorate 1999-2001 Programme on Sustainable Development. Paris, France, 7-56 (2001)

3. R. Shah, U.S. Sharama, A. Tivari, Sustainable Solid Waste Management in Rural Areas, international Journal of Teoretical \& Applied Sciences, 4(2),72-75 (2012)

4. U. A. Zaman, Comparative study of municipal solid waste treatment technologies using life cycle assessment method. Int. J. Environ. Sci. Tech., 7 (2), 225-234, Spring (2010)

5. E. Den Boer, A. Jędrczak, Z. Kowalski, J. Kulczycka, R. Szpadt, A review of municipal solid waste composition and quantities in Poland, Waste Management 30, 369-377(2010)

6. Directive 1999/31 / WE on the landfill of waste (WE L 182 16.07.1999)

7. Directive 2008/98 / WE on waste and repealing certain Directives (L 312 22.11.2008)

8. G. Przydatek, Factors of Changes in Waste Management in a Mountain Region of Southern Poland Journal of Ecological 20 (5), pages 86-96 (2019)

9. M. Faccio, A. Persona, G. Zanin, Waste collection multi objective model with real time traceability data. Waste Manag 31(12), 2391-2405 (2011)

10. Regulation of the Minister of the Environment of 9 December 2014 on waste catalogue (Journal of Laws 2014 item 1923), accessed http://www.sejm.gov.pl 12.05.2019

11. Statistics Poland (SP), http://bdl.stat.gov.pl/ accessed 12.04.2019

12. Act of 13 September 1996 on maintaining cleanliness and order in municipalities (Journal of Laws of 2018, item 1454), accessed http://www.sejm.gov.pl 12.05.2019

13. A. Johari, H. Alkali, H. Hashim, S.I. Ahmed, R. Mat, Municipal Solid Waste Management and Potential Revenue from Recycling in Malaysia, Modern Applied. Sceinces, 8(4) 42-45 (2014)

14. G. Przydatek, A. Comparative Analysis of Municipal Waste Management Systems. Pol. J. Environ. Stud. Vol. 25, No. 5, 2107-2112 (2016)

15. G. Przydatek, A. Kochanek, M. Basta, Analysis of Changes in Municipal Waste Management at the County Level, Journal of Ecological Engineering 18 (1), 72-80 (2017)

16. A. Macias, W. Piniarski, Municipal Solid Waste Management Problems on a Local Scale: A Case Study from Rural Poland, 1625-1628 (2016)

17. M. M. Tirado-Soto, F. L. Zamberlan, Networks of recyclable material waste-picker's cooperatives: An alternative for the solid waste management in the city of Rio de Janeiro, Waste management 33(4) 1004-1012 (2013)

18. G. Przydatek, D. Kamińska, K. Kostrzewa, An Analysis of Municipal Waste Management in a Selected Urban Municipality on the Basis of Selectively Collection. Renewable Energy Sources: Engineering, Technology, Innovation. Springer, 473-482 (2018) 